Jurnal Bisnis dan Manajemen, Volume 21, No. 1, March 2020, p. 43-56

\title{
EMPLOYING PEOPLE WITH DISABILITIES: ARE THEY COMPETENT AND PERFORMED?
}

\author{
Dina Sartika ${ }^{1}$, Aulia Devita ${ }^{2}$ \\ ${ }^{1,2}$ Universitas Padjadjaran, Indonesia
}

\begin{abstract}
The implementation of diversity management becomes a challenge for the company, primarily to employ those with physical disabilities. There is a stereotype in Indonesian society that those people are not able to work, especially in the formal sector due to their lack of competences that results in their low performance. Unfortunately, studies regarding the effect of competency towards employee performance of employees with disabilities have been very limited. This study aims at determining the influence of competency towards the performance of employees with disabilities in Thisable Enterprise. Data was conducted through a survey of 64 employees who are blind and deaf. Furthermore, the hypothesis test was carried out using multiple linear regression analysis. The results show that employees with disabilities in Thisable Enterprise have good competencies, consisting of intellectual competence, emotional competence, and social competence. The results of self-assessment, customer assessment, and evaluations from supervisors also showed that employee with a disability was able to provide good performance. Finally, the positive influence of intellectual competencies on performance was confirmed.
\end{abstract}

Keywords: competence, performance, employees with disabilities, diversity

\section{MEMPEKERJAKAN KARYAWAN DISABILITAS: APAKAH MEREKA KOMPETEN DAN BERKINERJA?}

\begin{abstract}
ABSTRAK
Keragaman atau heterogenitas tenaga kerja dinilai dapat menjadi aset bagi perusahaan apabila diterapkan dan dikelola dengan tepat. Namun, dalam penerapannya saat ini keragaman masih sulit untuk diterima dan menjadi tantangan bagi perusahaan. Tantangan keragaman ini masih mengarah kepada para penyandang disabilitas. Masalah kemampuan fisik masih menjadi kendala bagi banyak penyandang disabilitas untuk dapat berkarya khususnya di sektor formal karena stigma negative mengenai kompetensi dan kinerja mereka. Sayangnya, penelitian mengenai pengaruh kompetensi terhadap kinerja karyawan penyandang disabilitas di Indonesia masih sangat terbatas. Tujuan penelitian ini adalah untuk mengetahui pengaruh kompetensi terhadap kinerja karyawan penyandang disabilitas pada perusahaan Thisable Enterprise. Metode penelitian yang digunakan dalam penelitian ini yaitu deskriptif dan verifikatif. Pengambilan data penelitian dilakukan melalui survei terhadap 64 karyawan penyandang tuna netra dan tuna rungu. Selanjutnya, uji hipotesis dilakukan dengan menggunakan teknik statistik analisis regresi linear berganda. Hasil pengolahan data menunjukkan bahwa karyawan penyandang disabilitas pada perusahaan Thisable Enterprise memiliki kompetensi yang baik, terdiri dari kompetensi intelektual, kompetensi emosional, dan kompetensi sosial. Hasil self-assessment, penilaian dari pelanggan, dan penilaian dari atasan juga menunjukkan bahwa karyawan disabilitas mampu menghasilkan kinerja yang baik. Selanjutnya, hasil analisis regresi menunjukkan bahwa kompetensi intelektual memiliki pengaruh positif terhadap kinerja karyawan disabilitas.
\end{abstract}

Kata-kata Kunci: kompetensi, kinerja, karyawan disabilitas, keragaman

Korespondensi: Dina Sartika, S.E., M.Si., Ph.D. Fakultas Ekonomi dan Bisnis, Universitas Padjadjaran. Jln. Dipati Ukur No. 35 Bandung, 40135, Jawa Barat, Indonesia. Email: dina.sartika@unpad.ac.id 


\section{INTRODUCTION}

Diversity in the workplace currently becomes a prevalent issue in companies. Diversity covers a variety of employees' backgrounds in terms of culture, gender, religion, race, skills, even physical conditions. Diversity or heterogeneity of the workforce is considered to bring more varied experience and benefit for the companies. On the other hand, it entails new challenges and obstacles to overcome.

Diversity can be an asset within a company because it can help success and provide opportunities for companies to grow and develop. This is because diversity can bring new perspectives, ideas, and innovations to the organization with a variation of skills and capabilities of each employee. Furthermore, for those companies that want to expand globally, they should be able to apply diversity because it shows how companies uphold the existence of multiculturalism at work.

However, currently, diversity is still difficult to accept and become a challenge for the company. According to Ruben and Stewart (2006) there are five main areas which are challenges related to diversity, namely: stereotypes, cultural differences, discrimination, secret rules, and standards for success that are unknown to minorities and diverse people, as well as communication.

These conditions also happen to diversity management in Indonesia. The problem of physical ability is still an obstacle for many people with disabilities to be able to work specifically in the formal sector. Just like other humans, people with disabilities also want to get decent jobs and get the skills they can give to society. Act No. 8 of 2016 states that, "Every company must employ at least $2 \%$ of diffables (people who are differently able) from the number of employees for government companies, and $1 \%$ for private companies". People with disabilities are still difficult to get access and opportunities to work.

According to data released by Satuan Tenaga Kerja Nasional in 2017, the total workforce of people with disabilities in Indonesia amounts to 11 million. The percentage of persons with disabilities who are still unemployed is quite low, which is only $3.69 \%$ or around 400 thousand of the total workforce of persons with disabilities. In contrast, the percentage of persons with disabilities who work is $96.31 \%$ or around 10 million people. However, most of these disabilities work in the informal sector.

Low employment rates for people with disabilities in the formal sector can be attributed to several factors. Corporate concerns and misunderstandings in hiring employees with disabilities are one of the main obstacles (Millington, Rosenthal, \& Alan Lott, 1998). Most companies are still questioning the competence of persons with disabilities because of the limitations they have (Johnson, Greewood, \& Schriner, 1998).

People with disabilities have the potential to contribute to the companies. Due to the variety and nature of people with disabilities, they also 
Jurnal Bisnis dan Manajemen, Volume 21, No. 1, March 2020, p. 44-56

have diverse work capacities. Thus, people with disabilities remain competent. However, the skills, abilities, and productive potential they have are different.

Based on the explanation mentioned earlier, it shows that actually, people with disabilities are workers who are sufficiently competent and skillful. Unfortunately, the concern of employers in hiring them is still an obstacle. In fact, diversity of skills possessed by people with disabilities can be an asset for the company if the employers can utilize their competencies properly. Thus, their potential and ability can be maximized. As a result, productive performance can be achieved.

This study aims at identifying the competences possessed by employees with disabilities and verifying how it affects their performance. Specifically, this research answers the question of how intellectual competence, emotional competence, social competence, and performance of employees with disabilities? Moreover, how those competences affect the performance of employees with disabilities?

Studies on how competence affect performance has been widely implemented. However, a few of them investigated it on employees with disabilities, especially in Indonesia. Thus, this study contributes to organizational behavior and diversity research stream by examining whether the effect of competence on performance also applied for employees with disabilities.

\section{LITERATURE REVIEW}

Disability is a condition or function that is discussed relatively significant towards the standards of individuals or groups in general. According to Act No. 8 of 2016, Persons with Disabilities are "Every person who experiences physical, intellectual, mental, and / or sensory limitations for a long time in interacting with the environment can experience obstacles and difficulties to participate fully and effectively with other citizens based on equal rights".

Unlike disability, the term diffable comes from a combination of two words, namely Different and Able or Different abilities (Sukri \& Indartono, 2020). The term indicates that diffables are not defects or deficiencies, but rather refer to people with different abilities or do things differently. From its understanding, the connotation of the term diffable is far more positive than the word disability.

Research on diversity management has actually been carried out since the late 1980 s, when heterogeneity and differences, especially age, race, gender and nationality, were considered among workers within an organization. Dass and Parker (1999) state that workforce diversity has been seen as an opportunity, threat, difference, or even a problem. This leads to a number of different diversity management styles and will ultimately lead to different costs and benefits according to the conditions of each company.

Ely and Thomas (2001) state that the diversity of the workforce can increase organizational effectiveness, improve morale, 
make new market areas more accessible, and increase productivity. Furthermore, diversity can improve learning, creativity, flexibility, organizational and individual growth, and the company's ability to adjust quickly and successfully to market changes.

Regarding the correlation between competence and performance, Winanti (2011) found that competence has a close relationship with performance. Therefore, competency is very influential on employees' performance. Regardless of the type and level of work, employee work skills refer to the general competencies and non-technical competencies needed to do all the work. These skills are not specific to one job, but are considered as attributes of employees who make them company assets (Buck \& Barrick, 1987). The attribute in question shows that general competencies and non-skill competencies are part of each employee who cannot be separated regardless of the type and level in the company.

Competence is the ability of each individual which consists of knowledge, skills, attitudes, values, and personal characteristics that enable these individuals to succeed in completing their work (Noe, 2010). It is a combination of knowledge, skills, and personality that can improve individual performance so as to support the success of the organization.

Spencer and Spencer (1993) grouped three components of competencies namely: intellectual competence, emotional competence, and social competence. Intellectual competence refers to the overarching construct, including cognitive and non-cognitive traits that leads to differences in future achievement. On the other hand, emotional competence refers to the essential social skills to recognize, interpret, and respond constructively to emotions in oneself and others. Meanwhile, social competence consists of social and behavioral skills needed for successful social adaptation.

Competency can be a reference for employers since it is directly related to the personal abilities and characteristics of employees with disabilities and non-disabled people (Spencer $\&$ Spencer, 1993). The use of competencies can be considered when recruiting new employees because it can be adjusted to the competency standards that are really needed by the company.

Prior research on people with disabilities was conducted by Unger (2002) states that in reality, employees with disabilities have an average or above-average score on performance, safety records, and attendance based on company or employer ratings. In addition, Graffam et al. (2002) conducted a study of entrepreneurs in Australia who had experience employing people with disabilities. They found that employees with disabilities had lower values than the average employee on productivity factors (speed and accuracy), but were better than average employees on trust factors (absenteeism and sick leave) and employee maintenance factors (recruitment, safety, insurance costs). The overall results show that employers generally feel that employees with disabilities are productive and trustworthy with low cost of employee empowerment. 
Jurnal Bisnis dan Manajemen, Volume 21, No. 1, March 2020, p. 44-56

$\mathrm{Ju}$ et al. (2012) found that from the 5 constructs of employability skills including basic skills, high-level thinking skills, basic work skills, social skills, and personal traits, non-disabled employees did get slightly higher results compared to employees with disabilities. It leads to company's expectations to generally be greater for non-disabled employees than for disabled employees.

Powers' (2008) study focuses on the skills and productivity of disabled employees. He postulates that acquiring and demonstrating skills and competencies to employers are necessary for disabled people to succeed in a job. Moreover, skill development strategies are needed to elevate their productivity. These skills and productivity need to be effectively promoted to employers in order to overcome ignorance or prejudice towards disabled employees. Conversely, the willingness of employers to make relatively small adjustments to job design, regulation of work stations or production processes, or to allow workers to use tools and adaptive technology can significantly increase the productivity of disabled employees (Powers, 2008).

Based on that literature review, the proposed hypotheses are as follow:

H1: Intellectual competence has a positive effect on the performance of employees with disabilities. $\mathrm{H} 2$ : Emotional competence has a positive effect on the performance of employees with disabilities. H3: Social competence has a positive effect on the performance of employees with disabilities.
H4: Intellectual competence, emotional competence, and social competence simultaneously has positive effect on performance of employee with disabilities.

\section{METHODS}

\section{Research Object}

The object of this research is Thisable Enterprise company. Thisable Enterprise is a social enterprise that was founded in 2011 and has a mission to empower Indonesia's disability and enhance their wealth. Business activities that is conducted by Thisable Enterprise is facilitating training programs for persons with disabilities then channeling them to partner companies such as Gojek (with Go-Life consisting of Go-Massage, Go-Clean, Go-Auto, and Go-Glam), BUMN and private companies.

Thisable Enterprise has around 1000 databases of people with disabilities from all over Indonesia. However, around 200 people have been absorbed to be employed. Of the 200 employees with disabilities, as many as $85 \%$ or 170 employees are employed in Go-Jek (Go Life) and the remaining $15 \%$ are spread across six other companies (PGN, CIMB Niaga, Rabo Bank, General Electric, Bank Mandiri, and Infomedia Nusantara).

\section{Population and Sample}

Since the majority of people are channeled to Go Jek, then the population of this study is those who are employed at GoJek, amounting to 170 employees with disabilities. After conducting a 
calculation, the number of sample of this study is 62. The sampling technique used in this study was a non-probability sampling technique using a convenience sampling method.

\section{Data Collection Technique}

Data was carried out through a survey by distributing questionnaires to the respondents. There are two ways of data collection techniques. First, for respondents who are blind, the questionnaire was read by the researcher and ask their responses verbally. Then the researcher checked their answer on the printed questionnaire. Second, concerning deaf respondents, the researcher was assisted by an interpreter who translated the questions to sign language. Thus, we could check the response on the paper.

\section{Measures}

Survey items were generated based on a review of previous studies and published topical reports. Competencies are drawn into three draft section consisting of intellectual competence, emotional competence, and social competence. Intellectual competence $(\alpha=.85)$ was measured by five items questioning their level of skills, knowledge, analytical thinking, critical thinking, and problemsolving. Emotional competence $(\alpha=.87)$ was administered using a 5-item questionnaire, including caring for others, self-confidence, adaptability, sensitivity to others, and self-control. On the other hand, social competence $(\alpha=.90)$ was assessed using a 5-item questionnaire asking their ability to work as a team, give impact to others, lead and direct the team, as well as selfdevelopment. Lastly, performance $(\alpha=.86)$ was measured using 7-items questionnaire asking their performance with regard to quality, quantity, cost of effectiveness, timeliness, interpersonal impact, and need for supervision. Respondents rated the importance of each item on a 5-point Likert-type scale from strongly agree to strongly disagree.

The validity test was carried out using the Confirmatory Factor Analysis (CFA) test in SPSS software. Results indicate that all constructs value $>0.50$, which means that all indicator items used are valid.

In addition, to get more in-depth information, interviews with the leaders of Thisable Enterprise and some of the respondents were conducted. The qualitative data generated from these interviews strengthened descriptive analysis. Data were tested using multiple regression analysis techniques, which was performed by using IBM-SPSS Software 24 version.

\section{RESULTS AND DISCUSSION}

Tabel 1 of this study summarizes key characteristics of the respondents. The majority of respondents were male with age ranged from 25 to 45 years old. More than half of the respondents were married (58\%), and almost all respondents (97\%) are high school graduates. Regarding the tenure, most of the respondents (47\%) have been working with Go Jek for 1-2 years. Even $31 \%$ of them have been working for more than 2 years. 
The following are the characteristics of obtained from questionnaires:

respondents based on the recapitulation of data

Table 1. Respondents' Characteristics $(n=64)$

\begin{tabular}{|c|c|c|}
\hline Key characteristic & $n$ & Percentage \\
\hline \multicolumn{3}{|l|}{ Age } \\
\hline$\leq 25$ years old & 10 & 16.0 \\
\hline $26-35$ years old & 21 & 33.0 \\
\hline $36-45$ years old & 22 & 34.0 \\
\hline$>45$ years old & 11 & 17.0 \\
\hline \multicolumn{3}{|l|}{ Gender } \\
\hline Male & 55 & 86.0 \\
\hline Female & 9 & 14.0 \\
\hline \multicolumn{3}{|l|}{ Relationship Status } \\
\hline Married & 37 & 58.0 \\
\hline Single & 27 & 42.0 \\
\hline \multicolumn{3}{|l|}{ Education level } \\
\hline$\leq$ High school & 62 & 97.0 \\
\hline Diploma & 0 & 0.0 \\
\hline Bachelor & 2 & 3.0 \\
\hline$\geq$ Magister & 0 & 0.0 \\
\hline \multicolumn{3}{|l|}{ Working period } \\
\hline$\leq 6$ months & 11 & 17.0 \\
\hline $6-12$ months & 3 & 5.0 \\
\hline $1-2$ years & 30 & 47.0 \\
\hline$>2$ years & 20 & 31.0 \\
\hline \multicolumn{3}{|c|}{ Position as a GoJek (GoLife) partner } \\
\hline Go Massage & 25 & 39.0 \\
\hline Go Clean & 0 & 0.0 \\
\hline Go Glam & 0 & 0.0 \\
\hline Go Auto & 39 & 61.0 \\
\hline
\end{tabular}

Next, this study elaborates on each of the competence components possessed by disabled employees.

\section{Intellectual Competence}

Intellectual competence consists of five indicators, namely skills, knowledge, ability to think analytically, ability to think critically, and the ability to solve problems. The 5 indicators are contained in the five statements on the questionnaire which produce the data calculation as follows:

Table 2. Recapitulation of Intellectual Competency Score

\begin{tabular}{lc}
\multicolumn{1}{c}{ Indicator } & Mean \\
\hline $\begin{array}{l}\text { Sufficient skills in carrying out tasks and } \\
\text { work }\end{array}$ & 4,30 \\
$\begin{array}{l}\text { Sufficient knowledge in carrying out tasks } \\
\text { and work }\end{array}$ & 4,28 \\
$\begin{array}{l}\text { Ability to think analytically } \\
\text { Ability to think critically }\end{array}$ & 3,81 \\
$\begin{array}{l}\text { Ability to solve problems related to tasks } \\
\text { and work }\end{array}$ & 4,16 \\
Mean Score & 3,78 \\
\end{tabular}


Jurnal Bisnis dan Manajemen, Volume 21, No. 1, March 2020, p. 44-56

Table 3. Recapitulation of Emotional

The results in Table 2 show that the average score of intellectual competency is 4.07 . Skills are indicators with the highest average value of 4.30 . It indicates that employees with disabilities have sufficient skills and knowledge in doing their tasks and work. Moreover, they also possess the ability to think critically. These results are reinforced by a statement from the Project Coordinator of Thisable Enterprise which states that: "They (persons with disabilities) have different skills. For blind people, almost $70 \%$ of them have skills". Conversely, indicator with the lowest average score is the ability of employees to solve problems that is 3.78 . This dimension achieves the lowest average score because some people with disabilities still have a trust issue related to solving work problems because of their limitations.

\section{Emotional competence}

The next independent variable is emotional competence, which also consists of 5 indicators, including caring for others, self-confidence, adaptability, sensitivity to others, and self-control. The 5 indicators are contained in the five statements on the questionnaire which produce the data calculation as follows:

Competency Score

\begin{tabular}{lc}
\hline \multicolumn{1}{c}{ Indicator } & Mean \\
\hline Attitude of concern for others & 4,45 \\
Self-confidence & 4,45 \\
Ability to adapt to the environment & 4,34 \\
Sensitivity and sympathy for ohers & 4,41 \\
Good self control & 4,42 \\
Mean Score & 4,41 \\
\hline
\end{tabular}

Results in Table 3 show that the average score obtained on the five indicators reached 4.41. In accordance with the average score obtained, it can be said that employees with disabilities have a concern for others as indicated by relationships between partners (helping each other); have confidence that is shown by not giving up on the physical limitations they have; able to adapt to the environment indicated by the willingness to work and contribute to society; sensitivity to others is indicated by the willingness to help colleagues and other people in need; and being able to control themselves well is shown by the ability to control attitudes in serving customers.

These statements is reinforced by the results of interviews conducted with Talent Development of Thisable Enterprise which states that: "Employees with disabilities are quite confident, precisely with the existence of Thisable program. The confidence they have is increasing. As a talent development, I feel that there has been a significant change in them since the first interview until they start working with the company. Moreover, their ability to adapt to the environment is also increasing. This is because 
Jurnal Bisnis dan Manajemen, Volume 21, No. 1, March 2020, p. 44-56

the work environment does not only interact with fellow disabilities, but also with non-disabled customers. In addition, disability employees also have sensitivity towards others and are very solid."

\section{Social competence}

In the variable of social competence, there are 5 indicators including the ability to work with others, impact and influence, leadership, selfdevelopment, and directiveness. The 5 indicators are contained in the five statements on the questionnaire which produce the data calculation as follows:

\begin{tabular}{lc}
$\begin{array}{l}\text { Table 4. Recapitulation of Social Competency } \\
\text { Score }\end{array}$ & Mean \\
\hline \multicolumn{1}{c}{ Indicator } & 4,02 \\
\hline Ability to work with other people & 3,77 \\
Ability to influence and impact others & 3,67 \\
Ability to lead others & 3,86 \\
Ability to develop themselves and others & 3,81 \\
Ability to give direction to others & 3,83 \\
Mean Score & \\
\hline
\end{tabular}

The results in Table 4 show that the average score of social competence variable is 3.83 . This score is the smallest among other competences. The ability to lead others becomes the indicator with the lowest average score of 3.67, whereas the ability to work with others got the highest average score that reached 4.02. This is not surprising, given the limitations of employees with disabilities resulting in obstacles to interact with other people and their environment. However, there are also people with disabilities who have leadership attitudes and are able to become leaders. This is in accordance with the Personal Assisstant CEO of Thisable Enterprise's statement as follows : "People with disabilities can work with other people. Besides, among them there are also those who can become leaders for others".

The statement above shows that despite having limitations, disabled employees can work together with other people as long as the assignments are in accordance with their capacity. Besides, there are still doubts from disabled employees to lead others due to their limitation in communication.

\section{Performance}

The dependent variable in this study is the performance of employees which consists of 6 dimensions, namely quality, quantity, cost of effectiveness, timeliness, interpersonal impact, and need for supervision. The following table provides a detailed explanation of the responses of each indicator:

Table 5. Recapitulation of Performance Score

\begin{tabular}{lc}
\hline \multicolumn{1}{c}{ Indicator } & Mean \\
\hline Ability to work effectively & 4,14 \\
Ability to work efficiently & 4,09 \\
Ability to produce maximum output & 3,94 \\
$\begin{array}{l}\text { Ability to allocate costs effectively } \\
\text { Ability to complete assignments and work }\end{array}$ & 3,92 \\
$\begin{array}{l}\text { on time } \\
\text { Ability to have a positive impact on }\end{array}$ & 4,14 \\
colleagues & 4,17 \\
Ability to work independently without the & \\
need for supervision & 4,02 \\
& \\
Mean Score & 4,06 \\
\hline
\end{tabular}


Jurnal Bisnis dan Manajemen, Volume 21, No. 1, March 2020, p. 44-56

The results in Table 5 show that the average score of the performance variable is 4,06 . The ability to have a positive impact on colleagues (interpersonal impact) is the dimension with the highest average score that reached 4.17. On the contrary, the ability to allocate costs effectively got the lowest average score which only reached 3.92 .

On the quality dimension, which is divided into two indicators, namely effectiveness and efficiency, there are differences in the scores that have been achieved. The average score on the effectiveness indicator is higher than the average score on the efficiency indicator. This can be attributed to the experience of respondents who have so far been able to meet customer demand or completing orders.

In this research the statistical technique of multiple linear regression analysis was used to test the relationship between variables, namely intellectual competence (X1), emotional competence (X2), and social competence (X3) on employee performance variables (Y). The following table is a summary of the regression models:

Table 6. Summary of the Regression Model

\begin{tabular}{lcccc}
\hline \multicolumn{1}{c}{ Model } & $\mathbf{R}$ & $\begin{array}{c}\mathbf{R} \\
\text { Square }\end{array}$ & $\begin{array}{c}\text { Adjusted } \\
\text { R Square }\end{array}$ & $\begin{array}{c}\text { Std. Error } \\
\text { of the } \\
\text { Estimate }\end{array}$ \\
\hline 1 &, $860^{\text {a }}$ &, 739 &, 726 & 2,216 \\
a. Predictors: (Constant), Social Competence (X3), \\
Intellectual Competence (X1), Emotional Competence \\
$(\mathrm{X} 2)$
\end{tabular}

Based on the information above, the correlation coefficient value is categorized as very strong $(\mathrm{R}=.860)$ (Sugiyono, 2016). Furthermore, the coefficient of determination $\left(\mathrm{R}^{2}\right)$ is used to determine the percentage of influence between competency variables simultaneously on the performance variable. The coefficient of .739 obtained from the regression results shows that the variables of intellectual competence (X1), emotional competence (X2), and social competence (X3) simultaneously influence the employee performance variable (Y) of 73.9\%.

Moreover, hypothesis testing is done to prove whether the proposed hypothesis is accepted or rejected. Hypothesis testing is shown in Table 7 as follow:

Table 7. Analysis of the Regression Model Variance (ANOVA)

\begin{tabular}{|c|c|c|c|c|c|c|}
\hline \multicolumn{2}{|c|}{ Model } & $\begin{array}{c}\text { Sum of } \\
\text { Squares }\end{array}$ & df & $\begin{array}{c}\text { Mean } \\
\text { Square }\end{array}$ & $\mathbf{F}$ & Sig. \\
\hline \multirow[t]{3}{*}{1} & Regression & 834,885 & 3 & 278,295 & 56,655 &, $000^{\mathrm{b}}$ \\
\hline & Residual & 294,725 & 60 & 4,912 & & \\
\hline & Total & 1129,609 & 63 & & & \\
\hline
\end{tabular}

a. Dependent Variable: Peformance (Y)

b. Predictors: (Constant), Social Competence (X3), Intellectual Competence (X1), Emotional Competence (X2)

Based on the information above, hypothesis testing can be done by looking at the value of the $\mathrm{F}$ test and the significance value/p-value (Sig.) In the regression results obtained compared to the hypothesis proposed. The F test or the regression coefficient test is simultaneously carried out to determine whether the independent variables (X1, $\mathrm{X} 2$, and X3) together have a significant effect on the dependent variable (Y). The significance level used in this study is $5 \%$ or 0.05 . The hypothesis proposed in the $\mathrm{F}$ test is:

Ho: There is no significant influence between intellectual competence, emotional competence, and social competence simultaneously on employee performance 
Ha: There is a significant influence between intellectual competence, emotional competence, social competence simultaneously on employee performance

Based on the regression results in table 7 , the calculated $\mathrm{F}$ value is 56,655 . Furthermore, the $\mathrm{F}$ table value is 2.758 with the hypothesis test criteria used as follows: If the value of $\mathrm{F}$ count $>$ value of $\mathrm{F}$ table, then $\mathrm{Ho}$ is rejected and $\mathrm{Ha}$ is accepted. If the value of $\mathrm{F}$ count $<$ value of $\mathrm{F}$ table, then Ho is accepted, and Ha is rejected.

After comparison, the calculated $F$ value obtained based on the results of regression analysis $>\mathrm{F}$ table value $(56,655>2,758)$. Based on these results, then $\mathrm{Ho}$ is rejected, and $\mathrm{Ha}$ is accepted. This shows that there is an influence between intellectual competence, emotional competence, and social competence simultaneously on the performance of employees with disabilities.

In addition, significant influence between variables can also be known by looking at the significance value/p-value (Sig.). If the significance value/p-value (Sig.) < Significance level $(\alpha)$, then Ho is rejected, and Ha is accepted. Because the significance value/p-value obtained based on the regression results in table 4.18 is smaller than the significance level (Sig. $=0,000<$ $\alpha=0.05)$, then $\mathrm{Ha}$ is accepted. That is, there is a significant influence between the three competency variables with the variable performance of disability employees.

Moreover, the following is the model/result of the regression coefficient T-test of the competency variable on the performance variable based on the results of the regression analysis that has been carried out :

Table 8. Regression Coefficient Model

\begin{tabular}{|c|c|c|c|c|c|}
\hline \multirow[b]{2}{*}{ Model } & \multicolumn{2}{|c|}{$\begin{array}{l}\text { Unstandardized } \\
\text { Coefficients }\end{array}$} & \multirow{2}{*}{$\begin{array}{c}\text { Standardized } \\
\text { Coefficients } \\
\text { Beta } \\
\end{array}$} & \multirow[b]{2}{*}{$\mathbf{T}$} & \multirow[b]{2}{*}{ Sig. } \\
\hline & & $\begin{array}{l}\text { Std. } \\
\text { Error }\end{array}$ & & & \\
\hline 1 (Constant) & 1,927 & 2,267 & & ,850 & ,399 \\
\hline $\begin{array}{l}\text { Intellectual } \\
\text { Competenc } \\
\text { e (X1) }\end{array}$ &, 848 & , 131 & ,592 & $\begin{array}{r}6,46 \\
4\end{array}$ &, 000 \\
\hline $\begin{array}{l}\text { Emotional } \\
\text { Competenc } \\
\text { e (X2) }\end{array}$ & 270 & , 142 & ,192 & $\begin{array}{r}1,90 \\
5\end{array}$ & ,062 \\
\hline $\begin{array}{l}\text { Social } \\
\text { Competenc } \\
\text { e (X3) }\end{array}$ & ,172 & ,096 & , 173 & $\begin{array}{r}1,79 \\
4\end{array}$ &, 078 \\
\hline a. Dependent V & iable & orma & $(\mathrm{Y})$ & & \\
\hline
\end{tabular}

The first T-test was carried out on the intellectual competence variable to see the effect on the performance variable. Hypothesis testing is done by comparing the calculated $\mathrm{T}$ value with the $\mathrm{T}$ table value. The testing criteria is if the value of $\mathrm{T}$ count $>\mathrm{T}$ value of the table, then there is an influence between intellectual competence on employee performance or Ho is rejected, and $\mathrm{Ha}$ is accepted. The results in table 8 show that the calculated $\mathrm{T}$ value is $6.464>$ the $\mathrm{T}$-table value is 2,000 or Ha is accepted. That is, the results of the t-test show that intellectual competence influences employee performance.

Then, to find out the significant effect on the variables of intellectual competence on employee performance, the hypothesis test is done by comparing the significance values with the significance level used in the study. If the significance value (Sig.) < Significance level $(\alpha)$, then there is a significant effect between 
intellectual competence on employee performance or Ho is rejected, and $\mathrm{Ha}$ is accepted. The results in the table show the significance value of intellectual competence $(0,000)<$ probability level used (0.05) or Ha is accepted. The results of the comparison of significance values indicate that intellectual competence has a significant influence on employee performance.

The second T-test is then conducted to determine the relationship of emotional competency variables to performance variables. Based on the output results in table 10, the T value is $1.905<\mathrm{T}$ table value is 2,000 or $\mathrm{Ha}$ is rejected. The results of the t-test show that emotional competence does not affect employee performance.

The significance test results in the table show the significance value of emotional competence $(0.062)>$ the probability level used (0.05) or $\mathrm{Ha}$ is rejected. Thus, the result is emotional competence does not have a significant effect on employee performance.

The third T-test is conducted to find out whether social competence has an influence on employee performance. Based on the output results in the table shows the value of $\mathrm{t}$ count equal to $1.794<\mathrm{t}$ table value, which is 2,000 or $\mathrm{Ha}$ is rejected. This means the results of the t-test show that social competence has no influence on employee performance.

The significance test results in the table show the significance value of social competence $(0.078)>$ the probability level used $(0.05)$ or Ha is rejected. So, the result is social competence does not have a significant effect on employee performance.

In practice, good competencies are expected to be able to produce good performance. As previously explained, competence can be a reference for employers since it is directly related to the personal abilities and characteristics of employees with disabilities and non-disabled people.

People with disabilities have the potential to work, both as employees and as entrepreneurs. Due to the variety and nature of people with disabilities, they also have diverse work capacities. Sometimes, it is not a lack of skills or competencies that become reasons for persons with disabilities to be productive individuals, but physical barriers and organizations to utilize their skills at work.

The results of this study show that intellectual competence, emotional competence, and social competence of employees with disabilities were good, indicated by the high score of each competence indicators. These findings are inversely proportional to the negative stigma of persons with disabilities that was discussed by Niyu (2017), which suggested that the inherent "defect" stigma in persons with disabilities is often associated with people who have deficiencies or imperfections. It is a growing stereotype in the community that people with disabilities are portrayed negatively and are seen as less competent to work.

If we examined more deeply, the low work participation of persons with disabilities and the 
high level of concern of companies in employing them can be attributed to the existence of the negative stigma. The findings that persons with disabilities also have competencies should be considered by the company when recruiting employees. Thus, the practice of discrimination can be eliminated.

Concerning performance, the average score obtained based on the results of the descriptive analysis is also indicating a good performance of employees with disabilities. The findings are in line with previous research on persons with disabilities that have been conducted by Unger (2002), stating that in reality, employees with disabilities have an average or above-average score on performance, safety records, and attendance based on company ratings/employers.

Another study that also in line with the findings of this study is from Graffam et al. (2002) which shows that, in general, employers consider disability employees as productive and trustworthy employees with the cost of employee empowerment that is not too expensive.

On the other hand, the assessment of the customer is certainly a self-assessment balancer of respondents who are vulnerable to subjectivity. Of the 64 respondents, $77 \%$ of respondents have a higher rating than their assessment of themselves. This shows that the majority of respondents have good performance. Conversely, as many as $23 \%$ of respondents have a smaller rating compared to the results of their assessment of themselves. It can be said that there are a small number of respondents who have a subjective tendency to judge themselves.

\section{CONCLUSION}

Based on the results and discussion above, there are key points to conclude. First, employees with disabilities in Thisable Enterprise possess good intellectual competence, emotional competence, and social competence. Moreover, they were able to provide effective, efficient and optimal performance. This is reinforced by a direct assessment of the customer (rating on the application), which shows a positive average rating. Second, the results show that intellectual competence significantly influences employee performance. It can be concluded that intellectual competence has a positive relationship with the performance of employees with disabilities. Third, the second hypothesis, which stated that emotional competence significantly influences the performance of employees, is not proven as the $\mathrm{p}$ value indicated a non-significant result. The other hypothesis which stated that social competence has a significant effect on employee performance is also not proven as indicated by a non-significant result of the p-value. Lastly, intellectual competence, emotional competence, and social competence simultaneously have a positive relationship with performance.

This finding suggests that employers do not need to hesitate in employing people with disabilities. The stigma that they have a lack of competences and low performance was not proven through this study. Moreover, their disabilities are 
not supposed to be marginalized and excluded from employment. Giving them equal employment opportunities will protect their rights and allow them to reach their full potential.

\section{REFERENCES}

Buck, L. L., \& Barrick, R. K. (1987). They're Trained, but are They Employable? Vocational Education Journal, 62, 29-31.

Dass, P., \& Parker, B. (1999). Strategies for managing human resource diversity: From resistance to learning. Academy of Management Perspectives, 13(2), 68-80. https://doi.org/10.5465/ame.1999.1899550

Ely, R. J., \& Thomas, D. A. (2006). Cultural Diversity at Work: The Effects of Diversity Perspectives on Work Group Processes and Outcomes. Administrative Science Quarterly, 46(2), 229. https://doi.org/10.2307/2667087

Graffam, J., Shinkfield, A., Smith, K., \& Polzin, U. (2002). Employer Benefits and Costs of Employing a Person with A Disability. Journal of Vocational Rehabilitation, 17, 251-263.

Johnson, V. A., Greewood, R., \& Schriner, K. F. (1998). Work Performance and Work Personality: Employer Concerns about Workers with Disabilities. Rehabilitation Counseling Bulletin, 32, 50-57.

Ju, S., Zhang, D., \& Pacha, J. (2012).

Employability Skills Valued by Employers as Important for Entry-Level Employees With and Without Disabilities. Career Development for Exceptional Individuals, 35(1), 29-38. https://doi.org/10.1177/0885728811419167

Millington, M. J., Rosenthal, D., \& Alan Lott. (1998). Employment Expectation Profiles as a Differential Measure of EmploymentRelevant Attitudes Towards People with Disabilities. Utah State University, 28, 3941.

\section{McGraw-Hill Irwin.}

Powers, T. (2008). Recognizing Ability: The Skills and Productivity of Persons with Disabilities.

Ruben, B.D. \& Stewart, L.P. (2006). Communication and Human Behavior. 5th Edition, Pearson Education, Boston.

Spencer, L. M., \& Spencer, S. M. (1993). Competence at Work: Models for Superior Performance. John Wiley \& Sons, Inc.

Sukri, M., \& Indartono, S. (2020). Fulfillment of Education Rights for Diffable Students. 398(ICoSSCE 2019), 122-124. https://doi.org/10.2991/assehr.k.200130.026

Unger, D. D. (2002). Employers' Attitudes Toward Persons with Disabilities in the Workforce: Myths or Realities? Focus on Autism and Other Developmental Disabilities, 17(1), 2-10. https://doi.org/10.1177/10883576020170010 1

Winanti, M. B. (2011). Pengaruh Kompetensi Terhadap Kinerja Karyawan (Survei Pada Pt. Frisian Flag Indonesia Wilayah Jawa Barat). Majalah Ilmiah UNIKOM, 7(2), 249-267.

Noe, R. A. (2010). Employee Training and Development (5th Editio). New York: 